\title{
PENINGKATAN KETERAMPILAN MENULIS BERITA MELALUI MODEL PEMBELAJARAN KOOPERATIF TIPE JIGSAW SISWA KELAS VIII D MTS PONDOK PESANTREN AS-SALAM NAGA BERALIH KABUPATEN KAMPAR
}

\author{
Mardiah \\ STAI Auliaurrasyidin Tembilahan, Tembilahan, Indonesia \\ mardiah@stai-tbh.ac.id
}

\begin{abstract}
Based oninitial observation the fiel, the student news writing skills MTs Boarding School As-Salam Naga Beralih Kampar regency still low. This isi caused by several factors, one of which is the selection of the learning modeling accuracies. Learning model used is still the main choice in lecture learning. Another factor that comes from the students was the lack of motivation to write the story bacauce it was though that writing astoryisa difficult activity. To correct this condition carried through Classroom Action Research type Jigsaw Cooperative Learning Model. Purpose of this research class action (1) describing the process of improving the student skill in writing news items in class VIII D of class VIII d MTs boarding School As-Salam Naga Beralih Kampar regency increases trough Jigsaw cooperative learning model, and (2) describing the supporting factors improved writing skills class VIII D news MTs Boarding School As-Salam Naga beralih Kampar regency increases trough jigsaw cooperative learning model. Class room Action research was conducted in two cycles. Each cycle through the stages of (1) planning, (2) action, (3) observation, (4) reflection. The subjects were students of class VIII D Boarding School As-Salam Naga Beralih Kampar regency.The results of this study showed on increase in news writing skill class VIII D with respect to completeness of the content of the news ( $5 \mathrm{w}$ $=1 \mathrm{H}$ ), regularity of exposure, use of effective sentences, vocabulary used, the accuracy of using EYD, and attractiveness of headlines along with the formulation of several contributing factors in improving writing news class VIII D boarding School As-Salam Naga Beralih Kampar Regency. Jigsaw cooperative learning model type is suitable for use by teachersin teaching students to writing news. Teachers should choose appropriate learning steps in using the model of cooperative learning Jigsaw type new sin the learning process.
\end{abstract}

Keywords: skills, writing news, cooperative learning model, jigsaw type

\begin{abstract}
ABSTRAK
Berdasarkan pengamatan awal di lapangan, keterampilan menulis berita siswa MTs pondok Pesantren As-Salam Naga beralih Kabupaten Kampar masih rendah. Hal ini disebabkan oleh beberapa faktor, salah satunya adalah ketidaktepatan pemilihan model pembelajaran. Model pembelajaran yang digunakan masih ceramah menjadi pilihan utama dalam pembelajaran tersebut. Faktor lain yang berasal dari siswa adalah kurangnya motivasi untuk menulis berita karena ada anggapan bahwa menulis berita adalah kegiatan yang sulit. Untuk memperbaiki kondisi ini dilakukan Penelitian Tindakan kelas melalui model pembelajaran kooperatif tipe jigsaw. Tujuan penelitian tindakakn kelas ini (1) mendeskripsikan proses peningkatan keterampilan menulis berita siswa kelas VIII D MTs Pondok Pesantren As-Salam Naga Beralih Kabupaten Kampar melalui model pembelajaran kooperatif tipe jigsaw dan (2) mendeskripsikan faktor penunjang peningkatan keterampilan menulis berita siswa kelas VIII D Mts Pondok Pesantren As- Salam Naga Beralih Kabupaten Kampar melalui model pembelajaran kooperatif tipe jigsaw. Penelitian tindakan kelas dilakukan dalam 2 siklus. Masing-masing siklus melalui 4 tahapan, yaitu (1) perencanaan, (2) tindakan, (3) observasi, (4) refleksi. Subjek penelitian ini adalah guru dan siswa kelas VIII D Pondok Pesantren As-Salam Naga Beralih Kabupaten Kampar. Hasil penelitian ini menunjukkan terjadi peningkatan keterampilan menulis berita siswa kelas VIII D dengan
\end{abstract}

Peningkatan Keterampilan Menulis Berita melalui Model Pembelajaran Kooperatif Tipe JIGSAW

Siswa Kelas VIII D MTs Pondok Pesantren As-Salam Naga Beralih Kabupaten Kampar 
memperhatikan kelengkapan isi berita $(5 \mathrm{~W}+1 \mathrm{H})$, keruntutan pemaparan, penggunaan kalimat efektif, kosa kata yang digunakan, ketepatan penggunaan EYD, dan kemenarikan judul berita serta dirumuskannya beberapa factor penunjang dalam peningkatan menulis berita siswa kelas VIII D Pondok Pesantren As-Salam Naga Beralih Kabupaten Kampar. Model pembelajaran kooperatif tipe jigsaw sangat cocok digunakan oleh guru dalam pembelajaran menulis berita. Guru hendaknya memilih langkah pembelajaran yang tepat dalam menggunakan model pembelajaran kooperatif tipe jigsaw dalam prose pembelajaran berita.

Kata Kunci: keterampilan, menulis berita, model pembelajaran kooperatif, tipe jigsaw

\section{PENDAHULUAN}

Hasil pengamatan sementara menunjukkan masih banyak siswa MTs Pondok Pesantren As-Salam Naga Beralih Kabupaten Kampar yang tidak dapat menulis berita secara baik dan benar sesuai dengan kompetensi dasar yang ditetapkan dalam Kurikulum Tingkat Satuan Pendidikan yaitu menulis teks berita secara singkat, padat, dan jelas. Terkait dengan hal tersebut, fenomena yang tampak pada siswa kelas VIII D MTs Pondok Pesantren As-Salam Naga Beralih Kabupaten Kampar adalah sebagian besar siswa belum mampu menulis teks berita dengan baik. Pembelajaran menulis berita siswa kelas VIII D MTs Pondok Pesantren AsSalam Naga Beralih Kabupaten Kampar belum mencapai target $85 \%$ dan KKM 65. Sebagai gambarasnnya adalah hasil tes awal/ulangan harian siswa yang pernah dilakukan sebelum melaksanakan Penelitian Tindakan Kelas. Hasil tes awal/ulangan harian siswa yang sudah dilaksanakn ternyata keterampilan menulis teks berita siswa kelas VIII D MTs Pondok Pesantren As-Salam Naga Beralih Kabupaten Kampar 80\% belum mencapai Ketuntasan Minimal (65). Dari 33 siswa yang ikut tes awal/ulangan hanya 10 orang yang tentas dengan nilai 66-80 dan sebanyak 23 orang yang belum tuntas. Kenyataan ini menunjukkan bahwa keterampilan menulis teks berita siswa kelas VIII D Pondok Pesantren As-Salam Naga Beralih Kabupaten Kampar dalam menulis teks berita masih berkategori rendah dan perlu ditingkatkan.

Kesulitan-kesulitan yang dialami oleh siswa kelas VIII D di MTs Pondok Pesantren As-Salam Naga Beralih Kabupaten Kampar dalam mencapai kompetensi menulis teks berita harus dicarikan solusinya. Kemudian untuk mendapatkan hasil belajar yang memuaskan, guru harus mengupayakan agar siswa aktif dalam proses belajar. Guru diharapkan mampu memilih cara mengajar yang sesuai dengan materi pelajaran yang akan diajarkan, sehingga dapat mengaktifkan siswa dalam prose pembelajaran. Siswa daapt aktif jika diberikan model pembelajaran yang tepat. Pembelajaran aktif merupakan suatu cara untuk mengoptimalkan semua potensi yang dimiliki siswa sehingga dapt mencapi hasil belajar yang memuaskan. Secara rasional diperlukan juga model pembelajaran yang mempunyai pola pikir baru yang diharapkan dapat mengatasi masalah yang salam ini terjadi. Adapun model pembelajaran yang dimaksud adalah model pembelajaran kooperatif tipe jigsaw.

Tujuan yang akan dicapai dalam penelitian tindakan kelas adalah sebagai berikut. Yaitu (1) mendeskripsikan proses peningkatan keterampilan menulis teks berita siswa kelas VIII D MTs Pondok Pesantren As-Salam Naga Beralih Kabupaten Kampar melalui model pembelajaran kooperatif tipe jigsaw; dan (2) mendeskripsikan factor-faktor penunjang peningkatan keterampilan menulis teks berita siswa kelas VIII D MTs Pondok Pesantren As-Salam Naga Beralih Kabupaten Kampar melalui model pembelajaran kooperatif tipe jigsaw.

Penelitian ini mempunyai manfaat teoretis maupun praktis. Manfaat teoretis penelitian ini adalah dapat menambah pengetahuan tentang teori pembelajaran kooperatif tipe jigsaw. Secara praktis, penelitian ini dapat bermanfaat bagi (1) guru/kolaborasi di MTs Pondok Pesantren AsSalam Naga Beralih Kabupaten Kampar, khususnya guru mata pelajaran bahasa Indonesia untuk menambah pengetahuan dalam memahami dan menerapkakn proses pembelajaran dengan menggunakan model pembelajaran kooperatif tipe jigsaw sehingga hasil belajar dapat ditingkatkan 
khususnya pada mata pelajaran bahsa Indonesia; (2) Kepala Sekolah MTs Pondok Pesantren AsSalam Naga Beralih Kabupaten Kampar sebagai pertimbangan untuk dapat memberikan pembinaan kepada para guru di sekolahnya tentang penggunaan model pembelajaran kooperatif tipe jigsaw yang mungkin dapat diterapkan pada mata pelajaran lain; dan (3) Siswa, khususnya pada siswa kelas VIII D MTs Pondok Pesantren As-Salam Naga Beralih Kabupaten Kampar diharapkan dapat bermanfaat dalam upaya meningkatkan motivasi belajar sehingga kompetensi dalam mata pelajaran bahasa Indonesia berjalan secara optimal.

Berita adalah laporan mengenai suatu kejadian atau peristiwa actual yang menarik perhatian orang. Sama halnya dengan pendapat Kusumaningrat (2009:40) berita adalah informasi actual tentang fakta dan opini yang menarik perhatian orang. Berita juga dapat diartikan sebagai laporan atau pemberitahuan yang actual atau dapat juga dikatakan sebagai kabar, pengumuman tentang suatu peristiwa atau kejadian yang disampaikan melalui orang lain baik secara lisan atau tulisan. Hal ini sesuai dengan pengertian yang terdapat dalam Kamus Bahasa Indonesia Kontemporer (Salim dkk., 2002:190) berita adalah laporan atau pemberitahuan tentang suatu kejadian atau peristiwa yang disampaikan melalui orang lain baik secara lisan maupun tulisan. Berita adalah suatu fakta, ide atau opini actual yang menarik dan akurat serta dianggap penting bagi sejumlah besar pembaca, pendengar maupun penonton (Muda, 2008:22).

Tujuan utama penyajian berita adalah mengimformasikan peristiwa penting sebagai upaya untuk memberikan daya tarik agar orang mau membaca, mendengar, atdasu menonton sajian berita tersebut (Muda, 2008;22). Berdasarkan pendapat tersebut,dapat diambil kesimpulan bahwa berita adalah informasi actual tentang fakta dan opini mengenai kejadian atau peristiwa yang menarik perhatian umum atau memiliki nilai yang dianggap penting bagi sejumlah besar pembaca, pendengar, maupun penonton yang disampaikan melalui orang lain baik secara lisan maaupun tulisan.

Sebuah berita yang baik tidak akan melepas dari unsur-unsur pembentuknya, karena unsur-unsur itu ibarat system anatomi yang saling mendukung satu dengan yang lainnya. Umumnya para pakar sepakat bahwa di dalam sebuah berita ada 6 unsur, yang disingkat $5 \mathrm{~W}+1 \mathrm{H}$ (What, Who, Where, Whay, When, dan How) (Chaer, 2010: 18-19). Kalimat efektif adalah kalimat yang memiliki kemampuan untuk untuk menghadirkan kembali gagasan atau pemikiran yang ada pada pembaca persis seperti apa yang ada pada diri penulisnya. Pemahaman kalimat efektif ini sangat penting bagi para jurnalis dan penyunting bahasa. Adapun ciri-ciri khas kalimat efektif adalah sebagai berikut, yaitu (1) kesepadanan struktur; (2) keparalelan bentuk; (3) ketegasan makna; (4) kehematan kata; (5) kecermatan penalaran; (6) kepaduan gagasan; dan (7) kelogisan bahasa (Rahardi, 2010:52).

Model pembelajaran kooperatif model jigsaw adalah sebuah model belajar kooperatif yang menitikberatkan pada kerja kelompok siswa dalam bentuk kelompok kecil (Rusman, 2011:218). Dalam model belajar ini terdapat tahap-tahap dalam penyelenggaraannya. Tahap pertama siswa dikelompokkan dalam kelompokkelompok kecil. Pembemtukan kelompokkelompok siswa tersebut dapat dilakukan guru berdasarkan pertimbangan tertentu.

Menurut Rusman (2011:218) langkahlangkahnya adalah sebagai berikut, yaitu (1) siswa dikelompokkan dengan anggota lebih kurang 4 orang; (2) setiap orang dalam tim diberi materi dan tugas yang berbeda; (3) anggota dari tim yang berbeda dengan penugasan yang sama membentuk kelompok baru (kelompok ahli); (4) setelah kelompok ahli berdiskusi, tiap anggota kembali ke kelompok asal dan menjelaskan kepada anggota kelompok tentang subbab yang mereka kuasai; (5) tiap tim ahli mempresentasikan hasil diskusi; (6) pembahasan; dan (7) penutup.

\section{METODOLOGI}

Penelitian ini merupakan penelitian tindakan kelas (classroom Action Research). Penelitian ini dilaksanak dua siklus. Pada setiap siklus dilakukan 4 tahap, yaitu perencanaan, pelaksanaan tindakan, pengamatan, dan refleksi (Arikunto, dkk., 2008:74). Subjek penelitian ini adalah siswa kelas VIII D MTs Pondok Pesantren As-Salam Naga Beralih Kabupaten Kampar yang berjumlah 33 orang siswa. Langkah-langkah pelaksanaan dalam 
penelitian ini sebanyak 4 tahap, yaitu (1) perencanaan; (2) tindakan; (3) observasi; (4) refleksi. Penelitian ini dilakukan di MTs Pondok Pesantren As-Salam Naga Beralih Kabupaten Kampar, sebuah sekolah yang beralamat di Jalan Kabupaten bangkinang Seberang - Danau Bengkuang Km. 13 Naga beralih Kecamatan Kampar Utara Kabupaten Kampar Provinsi Riau. Data yang dikumpulkan adalah data kualitatuf dan kuntitatif. Bentuk tes yang digunakan dalam penelitian ini adalah (1) teknik tes, yaitu tes unjuk kerja yang tujuannya mengukur pencapaian siswa setelah mempelajari suatu materi pelajaran. Penilaian untuk tes unjuk kerja keterampilan menulis tesk berita diambil setiap akhir siklus yaitu dengan mengadakan postes; dan (2) teknik nontes (observasi dan catatan lapangan). Teknik pengabsahan data yang digunakan yaitu teknik triangulasi. Teknik analisis data yang digunakan ada dua, yaitu (1) teknik analisis data kualitatif dan (2) teknik analisis data kunatitatif.

\section{HASIL DAN PEMBAHASAN Kondisi Prasiklus}

Proses pembelajaran pada prasiklus dilaksanakan pada tanggall 03 Juli 2012 dan 05 Juli 2012. Materi pembelajaran adalah pengertian berita, pengertian kalimat efektif, pengertian kosa kata, penggunaan EYD, dan mempelajari judul yang menarik dalam teks berita. Pada kondisi prasiklus ini guru hanya melakukan sedikit latihan menulis teks berita pada siswa. Siswa disuruh menulis teks berita kemudian guru menjelaskan tentang bagaimana menulis teks berita yang baik.

Proses pembelajaran pada kondisi prasiklus belajarnya berpusat pada guru. Pada pertemuan pertama, guru menjelaskan materi pelajaran (unsur-unsur berita) di depan kelas. Siswa mendengarkan dan mencatat bagianbagian materi yang penting. Guru memberikan kesempatan kepada siswa untuk bertanya jika ada materi yang belum dipahami oleh siswa. Pada kondisi ini hanya beberapa orang siswa saja yang mau bertanya, itu pun siswa yang pintar dan siswa yang sudah sering bertanya. Siswa yang rendah kemampuannya belum berani untuk bertanya dan ketika guru bertanya kepada siswa tersebut, tidak bisa menjawab. Sepertinya siswa ini masih ada rasa takut, malu dan jiwa keberaniannya belum muncul. Setelah pembelajaran selesai guru memberikan pekerjaan rumah kepada siswa. Siswa disuruh mencari/menentukan unsur-unsur berita, kemudian unsur-unsur tersebut dikembangkan ke dalam beberapa paragraph sesuai dengan versi siswa.

Pada pertemuan kedua, guru melaksanakan pembelajaran sebagaimana biasanya. Guru menjelaskan materi pelajaran (kalimat efektif, EYD, kosa kata, dan judul berita) di depan kelas. Siswa mendengarkan penjelasan guru dan mencatat bagian materi yang penting. Sebagaimana biasanya, guru memberikan kesempatan kepada siswa untuk bertanya jika ada materi pelajaran yang belum dipahami. Siswa yang berani bertanya hanya siswa yang itu juga yaitu siswa yang pintar dan siswa yan g sudah sering bertanya. Siswa yang kemampuannya rendah dan sedang malu dan masih takut untuk bertanya. Setelah selesai proses pembelajaran, guru memeriksa pekerjaan rumah siswa yang siberikan pada pertemuan sebelumnya. Setelah diperiksa pekerjaan siswa tersebut, guru tidak langsung memberikan nilai. Namun ada coretan yang harus diperbaiki siswa dan siswa disuruh memperbaiki kalimat, kosa kata, EYD, dan judul berita sesuai dengan materi pelajaran yang sudah dipelajari beberapa menit yang lalu.

Pertamuan ketiga guru melaksanakan ulangan harian/tes prasiklus kepada siswa. Hasil ulangan/tes pada prasiklus menunjukkan hanya sebagian kecil saja siswa yang tuntas menulis teks berita. Pada umumnya siswa belum mampu menulis teks berita seusai dengan kelengkapan isis berita $(5 \mathrm{~W}+1 \mathrm{H}), \quad$ keruntutan pemaparan, penggunaan kalimat efektif, kosa kata yang tepat, ketepatan penggunaan EYD, dan kemenarikan judul. Siswa yang tuntas ketika ulangan/tes menulis teks berita yang diperoleh pada kondisi prasiklus hanya berjumlah 10 orang dengan presentasi $30,3 \%$, sedangkan siswa yang belum tuntas sebanyak 22 orang dengan presentase $66.6 \%$, dan siswa yang tidak ikut ulangan 1 orang. Satu orang siswa yang tidak hasir ketika ualngan/tes dikarenakan sakit.

\section{Siklus I}

Penelitian pada siklus I dilaksanakan sebanyak 
dua kali pertemuan proses pembelajaran dan satu kali pertemuan melaksanakan ualangan/postes. Data yang akan dipaparkan terdiri atas data perencanaan, evaluasi pembelajaran, dan hasil pengamatan, serta data hasil refleksi terhadap pelaksanaan tindakn pembelajaran.

a. Perencanaan

Penggunaan model pembelajaran tipe Jigsaw dalam perencanaan pembelajaran menulis teks berita diwujudkan dalam bentuk Rencana pelaksanaan Pembelajaran (RPP). RPP disusun dan dikembangkan berdasarkan kompetensi Mata Pelajaran Bahasa Indonesia MTs Kurikulum KTSP tahun 2006. Perencanaan pembelajaran pada siklus 1 disajikan dalam dua kali pertemuan. Setiap kali pertemuan disajikan dalam waktu $2 * 40$ menit atau dua jam pelajaran.

Rencana kegiatan belajar-memngajar pada pertemuan pertama pembahasannya mengenai unsur-unsur pokok verita (apa, siapa, kapan, di mana, mengapa, dan bagaimana). Langkah-langkah pembelajaran menulis teks berita pada pertemuan pertama terdiri atas kegiatan pendahuluan, kegiatan inti, dan kegiatan penutup. Kegiatan pendahuluan dilaksanakan lebih kurang 5 menit. Guru menyampaikan tujuan pembelajaran dan memotivasi siswa. Siswa mendengarkan penjelasan dari guru.

Kemudian dilaksanakan kegiatan inti selama 70 menit. Pada kegiatan inti pertama kali guru menyajikan atau menyampaikan informasi mengenai pembelajaran kooperatif tipe jigsaw. Siswa menyimak penjelasan dari guru. Guru mengorganisasikan siswa dalam kelompok-kelompok belajar yaitu lebih kurang 5 orang dalam satu kelompok asal. Seswa menggabungkan lebih kurang 5 meja menjadi 1 untuk masing-masing kelompok dan duduk dalam kelompok asal. Guru dan kolaborator memberikan materi/kertas kerja kepada kelompok asal dengan materi yang sama dan subbab berbeda. Siswa menerima materi/kertas kerja tersebut. Guru mengarahkan siswa agar membentukk kelompok ahi sesuai dengan materi/subjudul yang sudah diberikan. Siswa membentuk kelompok ahli dan mempelajari materi/subjudul yang sudah diterima dalam kelompok ahli. Guru membimbing kelompok ahli bekerja dan belajar. Siswa berdiskusi dengan kelompok ahli bekerja dan belajar. Siswa berdiskusi dengan anggota kelompok ahli. Guru memita perwakilan tiap kelompok asal mempresentasikan hasil diskusi mereka. Kegiatan akhir, guru memberikan penghargaan dengan kata-kata.

Rencana kegiatan belajar-mengajar pada pertemuan kedua pembahasannya mengenai penulisan teks berita (keruntutan pemaparan, kosa kata, kalimat efektif, EYD, dan judul berita). Langkah-langkah pembelajaran menulis teks berita pada pertemuan kedua terdiri ata kegiatan pendahuluan, kegiatan inti, dan kegiatan penutup. Kegiatan pendahuluan dilaksanakan selama lebiih kurang 5 menit. Guru menyampaikan tujuan pembelajaran dan memotivasi siswa. Siswa mendengarkan penjelasan dari guru.

Kemudian kegiatan inti dilaksanakan selalma 70 menit. Pada kegiatan ini guru menyajikan atau menyampaikan informasi mengenai pembelajaran kooperatif tipe jigsaw. Siswa menyimak penjelasan dari guru. Guru mengorganisasikan siswa ke dalam kelompokkelompok belajar yaitu lebih kurang 5 orang dalam satu kelompok asal. Siswa menggabungkan lebih kurang 5 meja menjadi 1 untuk masing-masing kelompok dan duduk dalam kelompok asal. Guru dan kolaborator memberikan materi/kertas kerja kepada kelompok asal dengan materi yang sama dasn subjudul berbeda. Siswa menerima materi/kertas kerja tersebut. Guru mengarahkan siswa agar membentuk kelompok ahli sesuai dengan materi/subjudul yang sudah diberikan. Siswa membentuk kelompok ahli dan mempelajari materi/subjudul yang sudah diterima dalam kelompok ahli. Guru membimbing kelompok ahli bekerja dan belajar. Siswa berdiskusi dengan kelompok ahli. Guru meminta perwakilan tiap kelompok asal mempresentasikan hasil diskusi mereka. Kegiatan akhir, guru memberikan penghargaan dengan kata-kata.

\section{b. Tindakan}

Tindakan pembelajaran siklus 1 dengan 
menggunakakn pembelajaran kooperatif tipe jigsaw dalam pembelajaran menulis teks berita siswa kelas VIII D di MTs Pondok Pesantren As-Salam Naga Beralih Kabupaten Kampar untuk pertama dilaksanakan Selasa, 20 Juli 2012, dan pertemuan kedua hari Kamis 12 Juli 2012. Berdasarkan perencanaan yang telah diuraikan di atas, penggunaan pembelajaran kooperatif tipe jigsaw dalam pembelajaran menulis teks berita dilaksanakan dalam tiga kegiatan yaitu pendahuluan, kegiatan inti, dan penutup.

\section{c. Observasi}

Dilihat dari lelmbar observasi siswa, dari 22 aspek yang diamati hanya 7 aspek yang mendapat skala/kategori sangat baik, 5 aspek yang mendapat skala 3/berkategori baik, 8 aspek yang mendapat skala 1/berkategori kurang, dan aspek yang mendapat skala 2/berkategori sedang 2 (dua). Aspek yang mendapat skala 4/berkategori sangat baik itu ada 7, yaitu (1) sopan santun belajar sesame teman; (2) sopan santun terhadap guru; (3) suasana PBM. Pada pembelajaran siklus 1 ini suasana $\mathrm{PBm}$ sudah sangat baik diandingkan suasana $\mathrm{PbM}$ sebelumnya. Suasana kegiatan PBM sebelum dilakukan pembelajaran kooperatif tipe jigsaw, masih ada siswa yang rebut, permisi keluar masuk kelas, dan tidur di dalam kelas; (4) kerjasama dalam kelompok. Pada siklus 1 ini kerjasama dalam kelompoknya sudah sangat baik dibandingkan sebelum dilaksanakan pembelajaran kooperatif tipe jigsaw. Sebelum dilaksanakan pembelajaran kooperatif tipe jigsaw, siswa lebih banyak diam dan tidak bergairah pada waktu proses pembelajaran berlangsung. Setelah dilaksanakan dengan cara berkelompok melalui tipe jigsaw, siswa sudah mulali berani untuk bertanya jawab dan mengeluarkan pendapat dalam kelompoknya; (5) keterlibatan dalam kelompok; (6) menghargai pendapat teman. Pada siklus 1 ini siswa sudah mulai menghargai pendapat temannya bahkan termasuk aspek berskala 4/berkategori sangat baik. Sebelum dilaksanakan pembelajaran kooperatif tipe jigsaw masih banyak siswa yang kurang menghargai pendapat temannya mungkin karena jiwa kebersamaan belum tertanam; dan (7) kelancaran PBM. Pada siklus 1 ini kelancaran PBM sudah sngat baik dibandingkan pembelajaran sebelumnya.

Dari hasil observasi yang dilakukan oleh kolaborator dapat diketahui bahwa model pembelajaran kooperatif tipe jigsaw pada siklus 1 belu, dikatakan sangat baik karena masih banyak mendapatkan skala 1/berkategori kurang dalam proses pembelajaran berlangsung dan ini perlu dilanjutkan ke siklus II. Dilihat dari tes unjuk kerja masih ada siswa mendapatkan nilai berkategori kurang atau mendapatkan skor yang sasngat rendah.

Data kuantitatif dalam penelitian ini merupakan hasil tes unjuk kerja keterampilan menulis teks berita dengan menggunakan model pembelajaran kooperatif tipe jigsaw siklus 1. Analisis ini bertujuan untuk mengetahui keberhasilan siswa dalam pembelajaran. Analisis data kuantitatif terdiri atas analisis analisis ketuntasan idividu, analisis ketuntasan klasikal, dan penghargaan kelompok.

1. Ketuntasan individu

Seorang siswa dikatakan tuntas dalam belajar apabila mencapai skor minimal $65 \%$ dari skor maksimal soal yang diberikan. Ketuntasan belajar secara individu dihitung dengan menggunakan rumus.

$$
\text { Ketuntasan }=\frac{\text { skor perolehan siswa }}{\text { skor maksimal }} \times 100 \%
$$

\begin{tabular}{|l|l|c|c|}
\hline \multirow{2}{*}{ No } & \multirow{2}{*}{ Keterangan } & \multicolumn{2}{|c|}{ Jumlah siswa pada } \\
\cline { 3 - 4 } & & Tes awal & Tes siklus 1 \\
\hline 1 & Tuntas & 10 & 24 \\
\hline 2 & Tidak tuntas & 22 & 9 \\
\hline 3 & Tidak hadir & 1 & 0 \\
\hline \multicolumn{2}{|c|}{ Jumlah } & 33 & 33 \\
\hline
\end{tabular}

\section{Ketuntasan Klasikal}

Ketuntasan belajar secara klasikal dihitung dengan menggunakan rumus. 


$$
\mathrm{KK}=\frac{\text { Jumlah siswa yang tuntas } \times}{\text { Jumlah seluruh siswa }} 100 \%
$$

Kriteria Ketuntasan Minimal (KKM) yaitu 65. indikator keberhasilan hasil belajar penelitian ini adalah apabila $85 \%$ siswa memperoleh nilai 65 dan di atas 65 .

\section{Tabel 2. Ketuntasan Klasikal Siklus 1}

\begin{tabular}{|l|l|l|}
\hline No & Keterangan & $\begin{array}{c}\text { Jumlah siswa } \\
\text { yang tuntas }\end{array}$ \\
\hline 1 & Tes awal & $30,3 \%$ \\
\hline 2 & Tes siklus 1 & $72,7 \%$ \\
\hline
\end{tabular}

\section{d. Refleksi}

Pada tahap ini, peneliti dan kolaborator mendeskripsikan hasil tindakan pada siklus 1 . Hal-hal yang didiskusikan menyangkut masalah kelemahan dan kelebihan pada tindakan yang telah dilaksanakan guru. Selanjutnya, temuantemuan tersebut dijadikan bahan pertimbangan untuk melaksanakan siklus berikutnya. Ada beberapa hal yang menjadi catatan peneliti dan kolaborator. Pada kegiatan refleksi ini melihat apa yang baikk dan apa yang kurang dari dalam melaksanakan proses pembelajaran.

Catatan temuan-temuan tersebut sebagai berikut. Pertama, melihat dari apa yang baik. (1) guru sudah berhasil mendidik siswa sopan santun belajar sesame teman; (2) guru sudah berhasil mendidik siswa sopan santun terhadap guru; (3) guru sudah berhasil mendidik siswa kerjasama dalam kelompok; (5) dan guru sudah berhasil mendidik siswa menghargai pendapat teman. Kedua, melihat apa yang kurang dari guru. (1) guru kurang memotivasi siswa; (2) guru kurang memperhatikan siswa ketika proses pembelajaran berlangsung; (3) guru kurang memberikan motivasi kepada siswa dalam mengajukan pertanyaan; dan (4) keterampilan menulis teks berita siswa dengan menggunakan kelengkapan isi berita $(5 \mathrm{~W}+1 \mathrm{H})$, keruntutan pemaparan, penggunaan kalimat efektif, kosa kata yang digunakan, ketepatan penggunaan EYD, dan kemenarikan judul belum optimal. Melihat kondisi ini guru berusaha untuk membantu siswa lebih giat belajar, memotivasi, dan memberikan strategi pembelajaran yang menarik yang dapat meningkatkan hasil tes unjuk kerjanya meningkat.

\section{Siklus II}

Penelitian siklus II pada pembelajaran menulis teks berita materinya yaitu yang berkaiatan dengan unsur-unsur berita beserta contohnya dan penulisan teks berita beserta contohnya. Kegiatan ini berupa kelanjutan dari siklus I yang terdiri atas dua kali pertemuan yaitu selasa 24 Juli 2012 untuk pertemuan pertama dan kamis 26 Juli 2012 untuk pertemuan kedua.

\section{a. Perencanaan}

Perencanaan pada siklus II yang terdir atas dua kali pertemuan yang dimulai dari pertamuan ketiga sampai pertemuan keempat. Setiap pertemuan disajikan dalam waktu $2 \times 40$ menit atau dua jam pelajaran. Materi yang dipilih pada siklus II ini sama dengan materi siklus I yaitu menulis teks berita. Perbedaannya terletak pada bentuk-bentuk tindakan yang digunakan dalam pembelajaran dan adanya contoh berita. Rencana kegiatan pembelajaran pada pertemuan ketiga difokuskan pada bentuk tindakan mendiskusikan unsur-unsur berita beserta contohnya. Unsur-unsur berita beserta contohnya yang didiskusikan sudah dipersiapkkan oleh guru dari rumah.

Langkah- langkah pembelajaran pada pertemuan ketiga (siklus II) terdiri atas kegiatan pendahuluan, kegiatan inti, dan kegiatan penutup. Kegiatan pendahuluan dilaksanakan selama lebih kurang 5 menit. Guru menyampaikan tujuan dan memotivasi siswa. Siswa mendengarkan penjelasan dari guru. Kegiatan inti dilaksanakan selama 70 menit. Guru megelompokkan siswa ke dalam kelompok asal. Siswa menggabungkan lebih kurang 5 meja menjadi 1 untuk masing-masing kelompok dan duduk dalam kelompok asal. Guru memberikan materi dan tugas kepada setiap siswa dalam kelompok asal dengan subbab yang berbeda. Dengan materi 6 unsurunsur berita (apa, siapa, kapan, di mana, mengapa, dan bagaima) beserta contohnya. Siswa mempelajari 6 unsur-unsur berita beserta contohnya yang sudah dibeerikan oleh 
guru dalam dalam kelompok ahli. Kegiatan akhir, guru memberikan penghargaan dengan kata-kata. Guru dan siswa bersama-sama menyimpulkan materi pelajaran yang telah dipelajari.

Rencana kegiatan belajar menagajar pada pertemuan keempat difokuskan pada bentuk penulisan teks berita (keruntutan pemaparan, kosa kata yang tepat, kalimat efektif, EYD, kemenarikan judul berita, dan unsur-unsur berita) beserta contohnya. Langkah-langkah pembelajaran terdiri atas kegiatan pendahuluan, kegiatan inti, dan kegiatan penutup. Kegiatan pendahuluan dilaksanakan lebih kurang 5 menit. Guru menyampaikan tujuan dan memotivasi siswa. Siswa mendengarkkan penjelasan dari guru. Kegiatan inti dilaksanakan selama 70 menit. Guru mengelompokkan siswa ke dalam kelompok asal. Siswa menggabungkan lebih kurang 5 menja menjadi 1 untuk masingmasing kelompok dan duduk dalam kelompok asal. Guru memberikan kepada setiap siswa dalam kelompok asal dengan subbab yang berbeda. Guru mengelompokkan siswa dalam ke dalam kelompok asal. Dengan materi teks penulisan berita (keruntutan pemaparan, kosa kata yang tepat, kalimat efektif, EYD, judul berita, dan unsur-unsur berita) beserta contohnya. Siswa mempelajari penulisan teks berita beserta contohnya yang sudah diberikan guru dalam kelompok ahli. Kagiatan akhir, guru memberikan penghargaan dengan kata-kata. Guru dan siswa bersama-sama menyimpulkakn materi pelajaran yang sudah dipelajari.

\section{b. Tindakan}

Tindakan penelitian siklus II terdiri atas dua kali pertemuan, yaitu pertemuan ketiga Selas 24 Juli 2012 dan pertemuan keempat Kamis 26 Juli 2012. Berdasrkan perencanaan sebelumnya, penggunaan pembelajaran kooperatif tipe Jigsaw dalam pembelajaran menulis teks berita dilalksanakan dalam tiga tahap yaitu pendahuluan, kegiatan inti, dan kegiatan penutup.

\section{c. Observasi}

Model pembelajaran kooperatif tipa jigsaw dalam pembelajaran menulis teks berita seperti ini telah membuat siswa aktif, kreatif, inovatif, efektif, dan menyenangkan. Keberhasilan pada siklus II diperoleh melalui pengamatan selama dan sesudah pembelajaran dilaksanakan. Kolaborator mengamati tindak mengajar guru yang mengajar dan tindak belajar siswa yang belajar dengan menggunakan lembar observasi. Bentukbentuk tindakan yang diamati mengacu pada penggunaan model pembelajaran kooperatif tipe jigsaw dalam pembelajaran menulis teks berita. Dalam pembejaran ini terjadi perubahan pada siswa, siswa lebih senang, aktif, dan mudah menemukan unsur-unsur berita serta mudah menyusun teks berita dengan memperhatikan keruntutan pemaparan, kosa kata yang tepat, kalimat efektif, EYD, dan kemenarikan judul.

Data yang diperoleh dari catatan lapangan menunjukkan bahwa siswa merasa senang dengan pembelejaran teks berita melalui model pembelajaran kooperatif tipe jigsaw. Hal ini dapat terlihat dari aktivitas siswa selama mengikuti pembelajaran. Siswa tampak lebih bersemangat dibandingkan pada pertemuan sebelumnya. Hal lain yang dikemukakan oelh siswa berkenaan dengan pembelajaran yang diikuti salah satunya dapat menambah pengetahuan tentang teks berita dan bertambah wawasan karena membaaca berita.

Data kuantitatif dalam penelitian ini merupakan hasil tes unjuk kerja keterampilan menulis berita dengan menggunakan model pembelajaran kooperatif tipe jigsaw siklus II. Analisis ini bertujuan untuk mengetahui keberhasilan siswa dalam pembelajaran. Analisis data kuantitatif teridri atas analisis ketuntasan individu, analisis ketuntasan klasikal, dan penghargaan kelompok.

\section{Ketuntasan Individu}

Seorang siswa dikatakan tuntas dalam belajar apabila mencapai skor minimal $65 \%$ dari skor maksimal soal yang diberikan. Ketuntasan belajar secara individu dihitung dengan menggunakan rumus. 
Ketuntasan $=\frac{\text { Skor diperoleh siswa }}{\text { Skor maksimal }} \times 100 \%$

Tabel 3. Ketuntasan Individu Siswa antara Tes Siklus I dan Tes Siklus II

\begin{tabular}{|l|l|c|c|}
\hline \multirow{2}{*}{ No } & \multirow{2}{*}{ Keterangan } & \multicolumn{2}{c|}{ Jumlah Siswa Pada } \\
\cline { 3 - 4 } & & es Siklus I & es Siklus II \\
\hline 1 & Tuntas & 24 & 31 \\
\hline 2 & Tidak Tuntas & 9 & 0 \\
\hline 3 & Tidak Hadir & 0 & 2 \\
\hline \multicolumn{2}{|c|}{ Jumlah } & 33 & 33 \\
\hline
\end{tabular}

\section{Ketuntasa Klasikal}

Ketuntasan belajar secara klasikal dihitung dengan menggunakan rumus.

\section{$\mathrm{KK}=\underline{\text { Jumlah siswa yang tuntas }} \times 100 \%$ Jumlah seluruh siswa}

Kriteria Ketuntasan Minimal (KKM) yaitu 65. Indicator keberhasilan hasil belajar dalam penelitian ini adalah apabila mencapai $85 \%$ siswa memperoleh nilai 65 dan di atas 65 .

\section{Table 4. Ketuntasan Klasikal Siklus II}

\begin{tabular}{|l|l|c|}
\hline No & Keterangan & $\begin{array}{c}\text { Jumlah siswa yang } \\
\text { tuntas }\end{array}$ \\
\hline 1 & Tes siklus 1 & $72,7 \%$ \\
\hline 2 & Tes siklus II & $93,9 \%$ \\
\hline
\end{tabular}

\section{a. Refelesi}

Berdasarkan hasil observasi dan tes menulis teks berita siswa selama siklus II guru/peneliti kolaborator mengadakan refleksi terhadap pelaksanaan tindakan pada siklus II. Dasri analisis data hasil pengamatan terlihat siswa sudah memperhatikan aspek unsur-unsur berita $(5 \mathrm{~W}+1 \mathrm{H})$, keruntutan pemaparan, kosa kata yang tepat, penggunaan kalimat efekti, EYD, dasn kemenarikan judul. Siswa banyak yang senang, serius, dan tidak meras kesulitan lagi ketika menulis teks berita, siswa secara umum sudah mencapai KKM yang telah ditetapkan dan dengan ketuntasan 93,9\%. Kemudian dari 22 aspek yang diamati pada lembar observasi, 19 aspek berkategori sangat baik dan 3 aspek kategori baik. Berkategori sedang dan kurang tidak ditemukan. Berdasarkan hasil tes tersebut peneliti dan kolaborator menganggap penelitian tidak perlu dilanjutkan.

\section{Aktivitas Belajar Menulis Berita Siswa Kelas VIII D MTs Pondok Pesantren As-Salam Naga Beralih Kabupaten Kampar melalui Model Pembelajaran Kooperatif Tipe Jigsaw}

Penggunaan model pembelajaran kooperatif tipe jigsaw dapat meningkatkan keterampilan dalam menggunakan kelengkapan isi berita $(5 \mathrm{~W}+1 \mathrm{H})$, keruntutan pemaparan, penggunaan kalimat efektif, kosa kata (bahasa yang tepat), ketepatan penggunaan EYD, dan kemenarikakn judul dalam menulis teks berita. Peningkatan terssebut dapat dibuktikan dengan melihat hasil tes menulis teks berita siswa yang terlampir diakhir laporan. Berikut ini akan dijelaskan masing-masing aspek yang difokuskan dalam menulis teks berita. Aspek tersebut meliputi kelengkapan isi berita, keruntutan pemaparan, penggunaan kalimat efektif, kosa kata, ketepatan penggunaan EYD, dan kemenarika judul.

Pertama, kelengkapan isi berita merupakan aspek yang cepat mengalami peningkatan yang cukup tinggi pada tiap siklus. Siswa sudah banyak yang mampu menulis kelengkapan isi berita dan mengeluarkan ide yang cukup bagus daslam menulis teks berita. Kedua, aspek keruntutan pemasparan, siswa sudah mampu menulis berita dengan urut dan jelas artinya sederhana, mudah dipahami, berirama/dinamis, semua ide tersampaikan dalam berita tersebut. Ketiga, aspek penggunaan kalimat efektif, kebanyakan siswa sudah mampu menulis berita singkat dan jelas artinya penyusunan kalimat singkat, jelas, dan mudah dipahami. Keempat, aspek kosa kata, kebanyakkan siswa sudash mampu menulis teks berita tepat dan mudah dipahami artinya kata-kata merupakan bahasa yang tepat, dinamis dan demokratis (bermakna satu), dan mudah dipahami. Kelima, ketepatan penggunaan EYD, sudah mampu menulis teks berita sesuai denga EYD artinya 
tidak ada kesalahan dalam penggunaan EYD. Keenam, kemenarikan judul, kebanyakan siswa menulis judul berita cukup menarik artinya judul yang digunakan cukup relevan dengan isi informasi dan kurang manarik untuk dibaca.

Faktor Penunjang Peningkatan Keterampilan Menullis teks Berita Siswa Kelas VIII D Mts Pondok Pesantren As-Salam Naga Beralih Kabupaten Kampar melalui Model Pembelajaran Kooperatif Tipe Jigsaw.

Factor penunjang dalam penelitian ini bisa diperoleh berdasarkan catatan lapang dan observasi yang telah dilakukan oleh kolabordator dan juga pengungkapan siswa dalam kegiatan refleksi. Seperti yang telah dijelaskan di atas factor penunjang dalam penelitian ini berasal dari beberapa segi. Factor penunjang yang dimaksud di sini merupakan factor yang sangat membantu dan mendukung penelitian ini berhasil dilakukan dan berjalan dengan lancer. Berikut ini akan diuraikan tentan $g$ faktor yang menunjang keberhasilan dalam penelitian.

Pertama, siswa merasa bahagia, riang, dan senang dalam belajar karena model pembelajaran kooperatif tipe jigsaw ini belajar secara bersama-sama atau berkelompok. Melalui model pembelajaran ini diberi kesempatan untuk mengajarkan materi yang mereka kuasai secara bergantian kepada temannya dan di sini mereka cukup senang karena merasa dirinya sangat berharga dan merasa dibutuhkan. Siswa merasa riang dalam belajar kooperatif tipe jigsaw ini karena dalam pembagian kelompok akademisnya heterogen (pintar, seddang, dan kuran g pintar).

Kedua, partisipasi kolaborator. Kolaborator sangat membantu dalam proses pembelajaran, seperti sering membantu guru dalaml mengontrol siswa. Kadang siswa sulit dikontrol oleh satu orang guru saja apalagi belajar kelompokk tipe jigsaw, siswa sering berpindah tempat duduk.

Ketiga, motivasi yang kuat dari guru. Motivasi guru sangat mendukung dalam proses pembelajaran. Hal itu bisa diperoleh dari catatan yang ditulis oleh kolaborator dan lembaran observasi. Walaupun pada siklus I motivasi yang diberikan guru masih belum kuat, tetapi pada siklus II motivasi yang diberikan guru sangat membantu. Dalam hal ini guru memotivasi siswa dengan cara memberikan penagandaian kepada sisw auntuk menjadi penulis yang terkenal dan bisa menjadi jurnalis yang terkenal.

\section{SIMPULAN}

1. Melalui pembelajaran kooperatif tipe jigsaw ini siswa lebih merasa bahagia, riang, dan senang. Melalui model pembelajaran kooperatif tipe jigsaw ini, siswa sudah mengalami perubahan yang cukup tinggi dibandingkan cara belajar sebelumnya. Dilihat dari proses pembelajarannya siswa sudah mulai termotivasi belajar dengan sungguh-sungguh.

2. Proses pembejaran menulis teks berita dengan model pembelajaran kooperatif tipe jigsaw dalam penelitian ini tidak terlepas dari factor penunjang. Dalam hal ini, faktor yang menunjang dalam penelitian ini yaitu jenis kegiatan ini yaitu jenis kegiatan belajar dengan model pembelajaran kooperatif tipe jigsaw sangat menyenangkan yang bisa membuat siswa merasa bahagia dan riang ketika proses pembelajaran berlangsung. Kemudian, adanya partisivasi kolaborator pada saat proses pembelajaran beralangsung. Selain itu, mativasi yang kuat dari guru, menyampaikan kata-kata baik yang bisa membangkitkan gairah belajar siswa meningkat.

\section{REFERENSI}

Arikunto, Suharsini dkk. 2008. Penelitian Tindakan Kelas. Jakarta: Bumi Aksara.

Chaer, Abdul. 2010. Bahasa Jurnalistik. Jakarta: Rineka Cipta.

Muda, Deddy Iskandar. 2008. Jurnalistik Televisi; Menjadi Reporter professional. Bandung: PT remaja Rosdakarya.

Kusumaningrat. 2009. Jurnalistik Teori dan Praktik. Bandung: Remaja rosdakarya.

Muslikah. 2010. Sukses Profesional Guru dan Penelitian Tindakan kelas. Yogyakarta: Interprebook.

Moleong, Lexi. 2004. Metodelogi Penelitian Kualitatif. Bandung: Remaja Rosdakarya. Metodologi Penelitian Kualitatif. Bandung: remaja Rosdakrya. 
Rahardi, Kunjana. 2010. Dasar-Dasar penyuntingan.; Bahasa Media. Yogyakarta: Gratama.

Riyanto, Yatim. 2001. Metodologi Penelitian Pendidikan. Surabaya: SIC.

Rusman, 2011. Model-Model pembelajaran; Profesionalisme Guru. Jakarta: raja Wali Pers.

Salim, Peter dkk. 2002. Kamus bahasa Indonesia Kontemporer. Jakarta: Modern English Press.

Silberman, Melvin L. 2010. Active Learning; 101 Cara Belajar Siswa Aktif. Bandung: Nusamedia dan Nuansa.

Suhandang, Kustadi. 2004. Pengantar Jurnalistik Seputar organisasi, Produk, dan Kode Etik. Bandung: Cendikia.

Suprijono, Aagus. 2009. Cooperative Learning; Teori dan Aplikasi Paikem. Yogyakarta: Pustaka Pelajar.

Tabrani. 2011. "Peningkatan Keterampilan Menulis Berita dengan pendekatan Kontekstual Komponen Pemodelan Siswa Kelas VIII A SMP Negeri 3 Bantan Kabupaten Bengkalis". Tesis tidak diterbitkan. Padang; Program Studi Pascasarjana UNP.

Trianto. 2009. Mendesain Model Pembelajaran inovatif. Jakarta: Kencana. 